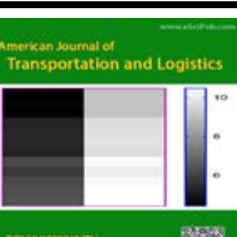

American Journal of Transportation and Logistics (ISSN:2637-6172)

\title{
Assessment of Transport and Logistics Education among Selected Universities in Southwestern Nigeria
}

\section{${ }^{1}$ Somuyiwa Adebambo and ${ }^{2}$ Adepoju Olusegun Onifade}

${ }^{1}$ Department of Transport Management, Faculty of Management Sciences; Ladoke Akintola University of Technology and Visiting Professor, Namibia University of Science and Technology,Windhoek, Namibia;

${ }^{2}$ Department of Transport Management, Faculty of Management sciences; Ladoke Akintola University of Technology, P.M.B. 4000, Ogbomoso, Oyo State, Nigeria

\section{ABSTRACT}

This paper assessed the Transport and Logistics Education as a University undergraduate programme being offered by some selected universities in Southwestern Nigeria. The specific objectives of this study are to examine the programmes of transport and logistics education with a view to understand areas where they are lagging behind across the selected Universities. Secondly, to determine those attributes that may facilitate qualitative education, not only in transport sector; but also at improving Nigerian universities education system. The total of 250 recently graduating students of the selected universities were randomly sampled and given both questionnaires and assessment form which covers six major subjects in the areas of Logistics and Transport. Descriptive analytical technique was used to achieve the first objective and Principal Component Analysis (PCA) was used to factorize fifteen identified variables and reduced it to eight principal components considered to facilitate qualitative education in Transport and Logistics Education in Nigeria. The results showcased the areas of strength and weaknesses of the selected schools and principal factors that must be available for qualitative logistics and transport education system in Nigeria.

Keywords: Evaluation, Transport and Logistics, Education, Nigerian Universities

*Correspondence to Author:

Adepoju Olusegun Onifade

Department of Transport Management, Faculty of Management sciences; Ladoke Akintola University of Technology, P.M.B. 4000, Ogbomoso, Oyo State, Nigeria

How to cite this article:

Somuyiwa Adebambo and Adepoju Olusegun Onifade. Assessment of Transport and Logistics Education among Selected Universities in Southwestern Nigeria.American Journal of Transportation and Logistics, 2019,2:12.

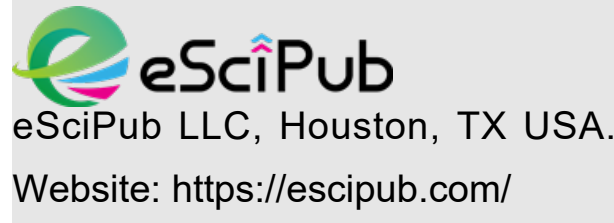




\section{INTRODUCTION}

Transport and Logistics education emerged in the continent through the ordinary and advance diploma programmes of the Charted Institute of Transport, London in the early 1960s (Oyesiku,2016). Transport and logistics education in Nigeria has not been given its right of place. The awareness of Transport and Logistics as academic discipline is perhaps still low and ambiguous. Somuyiwa (2017) explained further the statement of Oyesiku (2016) when he opined that, the introduction of structural adjustment programme in the $80 \mathrm{~s}$ shifted attention to seek for transport professionals. Chartered Institute of Logistics and Transport, London was one of the foremost transport institution issuing diploma in transport studies. However, transport is so diversified to cut across many areas such as purchasing and supply, maritime law, maritime studies, road transport management, transport management, logistics management, transport commerce, transport planning, logistics analysis, clearing and forwarding management, shipping and shipping law, piloting, air traffic control management, air craft piloting, flight operation and airport management (Oyesiku, 2016).

Many people seem not to clear cut the objective of the discipline based on different perceptions of what transport and logistics is as a course of study. According to Ogunsanya (2004); as at independence, there were relatively few qualified professionals available to carry out the essential tasks required by the transport sector in developing countries. The greatest challenge faced by the Nigerian university in the years after independence from Britain was whether to retain its British legacy, the gold standard of Lord Ashby of Brandon or open itself to other influences as is the case with universities all over the world; and gradually evolve a distinct character of its own. Again, much of the problems combating educational development in Nigeria had been attributed to poor funding.

In transport and logistics education, the cost required to train a prospective student is too enormous and perhaps more than what individual can shoulder especially practical related programs. In most cases, the better equipment required for the training led some affluent parent to seek for most suitable schools abroad. Transport is a multi-disciplinary subject matter with geographers, engineers, economists, political scientists, historians, lawyers, playing specific but complementary roles in its operation, management and research (Ogunsanya, 2004; Somuyiwa et al 2011). The complexity of transport and logistics education was expressed in Somuyiwa et al (2011) statement that; the issues of interest in transport as exhibited by the different disciplines, but interestingly no specific discipline has that monopoly of transport system analysis. The disciplines must work together in the effort to define acceptable concepts, theories and methodologies. They must draw from the same pool of academic knowledge in the pursuit of objectivity and truth in transport research.

Prior to now, the discipline of transport and logistics education existed as a subset of programmes in Nigerian Military schools. Similarly; at conventional universities, the programmes in Transport Management Technology and Transport Studies were pronounced at Federal University of Technology,Oweri (FUTO) and Olabisi Onabanjo University (OOU), Ago-Iwoye respectively. Although; at Olabisi Onabanjo University (formerly Ogun State University) it started at post-graduate level. In FUTO, the institution has options in Maritime and Transport Management. In year 2000/2001, Ladoke Akintola University of Technology (LAUTECH) Ogbomoso started the Transport Management as academic discipline. Federal Univeristy of Technology, Akure (FUTA) joined between 2006/2007 while Tafawa Balewa University, Bauch also follow and in year 2008 Lagos State University, Ojo (LASU) started her transport school. In an attempt to solve diverse transportation problems experienced daily in 
Lagos State, Nigeria; LASU in collaboration with CILT initiated advanced Diploma in Transport and Logistics and Transport. The school also partners with National Transit Institute at Rutgers University in New York, for the purpose of in-service training of staff of transport agencies and operators through short term courses (Bawa-Allah, 2008). LASU's school of transport has three departments (Transport Planning and Policy, Transport Technology and Infrastructure and Transport Management and Operations). Redeemer's University of Nigeria offers the course as Transport and Tourism as one of the private institutions to start transport and related programme. Nigerian Institute of Transport Technology (NITT) was also created to enhance the country's development in transport and allied disciplines technology.

One very crucial issue about transport and logistics programme as academic discipline is the fact that it cuts across available modes of transport. Hence, it is difficult to structure the various subjects and components to be covered in course curriculum. For instance, Transport Planning as it programme being called at Tai Solarin University of Education is different from Transport Management in LAUTECH and consequently Transport Management Technology of FUTA. Regrettably however, most institutions cannot distinguish the differences in the objectives of their establishment. The obscurity present in the award of degree of Bsc, B.Tech and BA has not been properly delineated in most Nigerian schools. However, the objective of setting up a particular university is to recruit and train qualified candidates for and or create employment and innovatively enhance organizational goals and national development. Romina (2013) citing (World bank, 1999) asserted that higher education has been recognized as a fundermental instrument for the construction of a knowledge economy and the development of human capitals all over the world. Such high level educational provision enables the citizens to acquire skills and techniques which are ploughed into human productivity, creativity, competence, initiative, innovation and inventiveness (Ehiametalor, 1988).

Transport as a course of study cannot be made complete without practicing the practical aspects of it. To one's dismay, universities' curriculum is not augmented with practical skills in order to mirror the needful operational skills required in transport industries. Meanwhile, National Universities Commission (1989) expressed that, general philosophy of curriculum development aims at developing the total being in this connection, the curriculum should develop the mind and impart theoretical and practical knowledge that would encourage self-reliance in the individual and of the nation stressing that it should enable him to understand, exploit, and if necessary, change his environment. For transport studies, or Transport and logistics as the case may be; there seems to be lack of coherency in structure among institutions offering the course(s). Based on hierarchy of importance of the course(s), weights or units are assigned to the courses and these vary across universities. Meanwhile, there seems to be difference between education and training. Education mostly deals with theoretical teachings without much practical training. Whereas; training has to do with application of what has been taught so as to gain requisite skills in carrying out specific tasks. Most training required for maritime and aviation operations involve practical skills that cannot be gotten through class room theoretical lectures. All relevant areas that graduates of transport studies will likely work should be covered by the curriculum. For instance, various opportunities for graduates of transport studies in relation to all the available modes of transport can be but not limited to the identified ones: Jobs in Air transport include-Ticketing and Reservation, airport officials, airline managers, cargo handlers, hopper services, port agents, 
consultancy services agent, airport security service providers, with further training cabin crew, airline protocol officer e.t.c. Jobs in Maritime transport- include clearing and forwarding agents, customs, port police, stevedore, cargo handler, port manager, maritime business services provider, merchant navy officer, importer and exporter, port administrator, e.t.c. In rail transport, yard maintenance officer, rail track monitoring officer, e.t.c. In road transport and logistics, there are so many areas to function, for example; haulage and distribution, bus operation, car hire service, tourism, taxi operation, motorcycle and tricycle operations, e.t.c. In transport studies, prospective students often get confused as they do not actually understand whether they will become drivers at the end of studying five-year programme at the end of the university education. This paper was written to identify the gap between what should be expected of Transport and Logistics Education as a course of study in Nigerian Universities with a view to solving myriads of transportation problems relating to the underlisted across various segments and modes of transport:

(1) Safety in transport services and operations

(2) Reliability of transport service provision

(3) Adequacy of transport service provision

(4) Accident and traffic laws/ control of transport operations

(5) Environmental friendliness of transport operations

(6) Maintainace and management of transport infrastructure

(7) Importation and exportation of goods

(8) Transport planning and urban/rural land use

(9) Terminals management (seaport, Airport, Railyard, Bus stops, Container Depots,e.t.c)

(10) Managing movement of available modes of transport

(11) Designing more technological means to improve transport systems

(12) Management of vehicle operations for profitability in transport industries
(13) Efficient utilization of transport assets, personnel and resources

(14) Administration and management of transport operations

\section{LITERATURE REVIEW}

The essence of University and other higher education is to equip students with adequate knowledge that can be utilized on the field and industry in order to innovatively contribute to national growth and developments. According to Romina (2013) and Federal Ministry of Education (2004) section 8 (59), the followings are the aims of higher education in Nigeria:

- Contribution to national development through high level manpower training.

- Development and inculcation of proper values for the survival of the individual and the society.

- Development of the intellectual capabilities of the individual to understand and appreciate their local and external environment.

- Acquisition of both physical and intellectual skills which will enable the individual to be self-reliant and useful member of the society.

- Promotion and encouragement of scholarship and community services.

- For national unity and the promotion of national and international understanding and interaction.

Section 8 (60) of the federal ministry of education also state that higher education in Nigeria should vigorously pursue these goals through:

(a)Teaching (b) Research and development (c) Knowledge generation and dissemination and international cooperation (e) Dedicated services to the communities through extra-mural and consultancy service.

According to Somuyiwa (2017) "The quality of education in building a collection of traits in relation to knowledge, habits, creativity, personality and unprecedented wisdom in a discipline embodied in ability to perform 
efficiently and add to general value can be referred to as Human Capital Development. In transport and logistics education however, the bane of qualitative education arise from the structure, perception and complexity of inter and intra (maritime, rail, supply chain and logistics, aviation and transport \& environment) modalism which needed to be shredded in Transport and Logistics Education for the purpose of specialization and qualitative human capital development. Furthermore, in today's world; forces of globalization, technology and competition continue to redefine both military and commercial logistics making it harder than ever for managers, professionals and instructors to rely on traditional concepts, approaches, techniques, methods or processes that not only obsolete but dangerous".

However, there are so many factors militating against the achievements of the stated aims. Teaching transport courses and programmes requires experience. It was reiterated by (Olson and Wyett, 2000) that, as far as teachers are concerned, selection is much more important than training. Teachers are the most important resource in an educational institution. They instill morals, principles, ethics and virtues expected of students after school life. Hence, the personality and attitudes of teachers are just as important as their knowledge of subject matter and pedagogic skills (Olson and Wyett, 2000). Romina (2013) expressed that; according to Coombs (1970), teachers are the hub of any educational system. Teachers determine the quality of education because they transmit educational policies into practice and action. Ukeje, (1996) without adequate number of inspiring, well-informed teachers, fully prepared to meet their responsibilities in our schools, we cannot have good education and without good education, we cannot hope for long to meet successfully, the challenges of a changing world. Curricular supposed to be developed out of experience and experienced people can develop it. Education is experience, and experience is education Onah (1979). The experience of teachers matter and the way he/she has received or undergone his training, exposure to different methods of teaching and observations of practical aspect of transport in order to gain insight for developmental research is crucial of teaching skills. Ighodo (2011) expressed the problem of quality in Nigerian universities and explained it complexity in the areas of political influence. According to Ogunsaya (2004), transport programmes should cover the followings areas: Transport operations and management, transport environment and energy issues, transport demand and supply, transport infrastructural provisions and transport technology. All these areas have other embedded sub programmes. Although the itemized captured the relevant areas in transport but, fundamentally it has not been tailored to specific modes of transport (Maritime, Aviation, Pipeline, Rail and Road). Automobile and pipeline transport have not been fully captured in most Nigerian universities' transport programmes.

World Bank (2004) argued that, investment in education is its functionality and the bottom line for functionality is quality in education. In Nigeria, quality education appears elusive because the five well known inputs into learning are not of the right quality (1) students - their capacity and their motivation to learn (2) the subjects to be learned (3) the teacher who knows and can teach the subjects (4) time for learning and (5) the requisite tools for teaching.

Ezenyilimba (2015) enumerated challenges and various combating educational sector in Nigeria from the issue of curriculum development, inadequate quality management strategies, staff recruitment process, proliferation and duplication of professional bodies, poor power supply, inadequate infrastructural facilities and effective transport system. Funding is another area where some of the universities are facing challenges and has made some brilliant lecturers to leave the country. Many instructor or teacher refused to upgrade themselves so as to be able to use modern equipment. Activities 
of higher educational institutions have been highlighted as teaching, research and scholarship, community service, staffing, students, infrastructures and educational facilities, equipment and the academic environment (World conference on higher education, 1998). Meanwhile, achieving all the relevant aims of higher education is through qualitative education. Quality higher education entails that the products of institutions of higher education should be able to perform according to expected standard and compete favourably with their peers in other countries of the world. Quality education is the education that produces a complete person. Complete in the sense that the person is intellectually, morally, physically, emotionally and socially developed. Hence Akinpelu, (2000) argued that education without quality can even be more dangerous than no education, stressing that without quality, education has no value. In order to boost the relationship between "gown and town" i.e theory and practice, the government introduced the Student Work Experience Scheme (SIWES). Yet, the gap between classroom and industry has not been bridged. Especially in transport, experience can not be received from its multi-faceted areas within little period of time specified for SIWES.

Researchers like Bamiro (2012) Akinmusuru (2009) Kamm (1980) asserted that, quality of education in Nigeria has been deprived as a result of lack of good textbooks, library, equipment and infrastructural facilities, and qualify teachers. Many maritime institutions in developing countries do not possess training vessel(s) in order to accomplish practical training process. Neither do they have engine room simulators that could be used to bring the interface on theoretical and practical training (Yassin, 2000). Okebukola (2005) as the former Executive Secretary (National University Commission) NUC noted that, only about $30 \%$ of Nigerian students' population has adequate access to classrooms, workshop, lecture halls, laboratories and libraries. Industrial actions, salary issues and strike by academic and non academic unions and inadequate facilities are the problems of the university system. Even with various measures put in place by NUC, these challenges are still present. To curb nepotism and favoritism in grading students, some universities adopted conference marking as a measure.

The university programmmes in transport attempted to achieve quality by incorporating the professional bodies into there programmes. However, the difference between the two programmes is not clear. There are practical skills that can enhance the industry at both levels which has made many people not to be serious about joining the bodies as they will still continue to make membership payments without any concrete benefit. Conversly, Oyesiku (2016) compared the competency and performance of 50 Diploma holders of CILT programmes and found out that, diploma certificate holders are well groomed and competent at their various organizations whereas those that possessed masters degrees are not as good as them partly due to various backgrounds as their first degrees.

\section{METHODOLOGY}

According to UTME (2015) brochure, the following universities were accredited to run transport and logistics related programmes:

- Ladoke Akintola University of Technology, Ogbomoso, Nigeria

- Olabisi Onabanjo University, Ago Iwoye

- Tafawa Balewa University, Bauch, Bauchi Nigeria

- Federal University of Technology, Owerri, Imo state Nigeria

- Federal University of Technology, Minna, Niger State

- Federal University of Technology, Akure, Ondo State

- Redeemer's University of Nigeria, Ede, Osun State

- Lagos State University, Ojoo, Lagos State 
- University of Lagos

- University of Port Harcourt

Table 1: Transport and Logistics Institutions in Nigeria

\begin{tabular}{|c|c|c|c|c|c|c|}
\hline \multirow[t]{2}{*}{$\mathbf{S} / \mathbf{N}$} & \multirow[t]{2}{*}{ INSTUTUTIONS } & \multirow[t]{2}{*}{ PROGRAMME } & \multicolumn{4}{|c|}{ Level of Programme } \\
\hline & & & Diploma & B.Sc. & M.Sc. & PhD \\
\hline 1 & $\begin{array}{ll}\text { AdekunleAjasin } & \text { University, } \\
\text { Akangba-Akoko } & \end{array}$ & Transport and Planning & & & & \\
\hline 2 & $\begin{array}{l}\text { Federal University of Technology, } \\
\text { Akure }\end{array}$ & $\begin{array}{ll}\text { Transport } & \text { Management } \\
\text { Technology } & \\
\end{array}$ & & & & \\
\hline 3 & $\begin{array}{lll}\text { Federal university } & \text { and } \\
\text { Technology, Minna } & \\
\end{array}$ & $\begin{array}{ll}\text { Transport } & \text { Management } \\
\text { Technology } & \\
\end{array}$ & & & & \\
\hline 4 & $\begin{array}{l}\text { Federal University of Technology, } \\
\text { Owerri }\end{array}$ & $\begin{array}{ll}\text { Transport } & \text { Management } \\
\text { Technology } & \\
\end{array}$ & & & & \\
\hline 5 & $\begin{array}{l}\text { Ladoke-Akintola University of } \\
\text { Science and Technology }\end{array}$ & Transport Technology & & & & \\
\hline 6 & Lagos State University, Ojo, Lagos & Transport Technology & & & & \\
\hline 7 & $\begin{array}{l}\text { Olabisi Onabanjo University, Ago- } \\
\text { Iwoye, Ogun State }\end{array}$ & $\begin{array}{l}\text { Transport Planning and } \\
\text { Management } \\
\text { Now Transport and Logistics } \\
\text { Management }\end{array}$ & & & & \\
\hline 8 & $\begin{array}{lll}\begin{array}{l}\text { Redeemers' } \\
\text { Ogun State }\end{array} & \text { University, } & \text { Mowe, } \\
\end{array}$ & Transport Management & & & & \\
\hline 9 & $\begin{array}{l}\text { Tai Solarin University of } \\
\text { Education, ljebu-Ode, Ogun State }\end{array}$ & Transport Planning (Education) & & & & \\
\hline 10 & $\begin{array}{l}\text { University of Lagos, Akoka, Lagos } \\
\text { State }\end{array}$ & $\begin{array}{lll}\begin{array}{l}\text { Transportation } \\
\text { Management }\end{array} & \text { Planning } & \text { and } \\
\end{array}$ & & & & \\
\hline 11 & $\begin{array}{l}\text { University of Port-Harcourt, Port- } \\
\text { Harcourt }\end{array}$ & $\begin{array}{lll}\begin{array}{l}\text { Transport } \\
\text { Management }\end{array} & \text { And } & \text { Logistics } \\
\end{array}$ & & & & \\
\hline 12 & $\begin{array}{l}\text { Nigerian Institute of Transport } \\
\text { Technology, Zaria (NITT) }\end{array}$ & $\begin{array}{l}\text { (i) Transport Operations and } \\
\text { Management } \\
\text { (ii) Transport Engineering } \\
\text { Technology } \\
\text { (iii) Transport studies }\end{array}$ & & & & \\
\hline 13 & Nigerian Maritime Academy, Oron. & $\begin{array}{l}\text { Certificates, Diplomas in Maritime } \\
\text { Studies }\end{array}$ & & & & \\
\hline 14 & $\begin{array}{l}\text { Chartered Institute of Logistics and } \\
\text { Transport, Nigeria }\end{array}$ & Logistics and Transport & & & & \\
\hline
\end{tabular}

Source: Oyesiku (2016) and Department of Transport, 2010; http://nces.ed.gov/ipeds/datacenter/; http://www.onetonline.org/find/industry; https://datadirect.aacsb.edu/public/profiles/ search.cfm \#results

Due to accessibility to data needed for the purpose of this research, the Universities selected were Southwestern Universities offering transport and related studies. The sampling of the slected Universities was based on the years they introduce the programme. Hence, Universities that started the programme after year 2008 were not considered. Therefore, the following Universities wers selected:

Ladoke Akintola University of Technology, (LAUTECH) Ogbomoso, Nigeria

Olabisi Onabanjo University, Ago Iwoye (OOU)

Federal University of Technology, Akure, Ondo State (FUTA)

Redeemer's University of Nigeria, Ede, Osun State (RUN)

Lagos State University, Ojoo, Lagos State(LASU)
The curricular of the selected universities were taken from their students' handbook so as to compare the courses undertook which enabled the researchers to formulate questions for both questionnaires and assessment form. However, 50 students (fresh graduates) of each selected school were purposively sampled through the aid of questionnaires and assessment for asking questions about the knowledge of the students on the course of study and factors they observed contributed to facilitating qualitative or undermine qualitative education in Nigeria. Total numbers of 250 graduates were randomly sampled for the purpose of this research.

\section{RESULT AND DISCUSSION}

The results of the assessment for among the selected graduates of the university were 
graded and the figure 4.1 showcased the analysis of the results in the following cogent six areas of Transport and Logistics Education.

\section{1) Road Transport \& Logistics} Management: the questions asked are in relation to fleet management, marketing operations of transport, physical distribution and logistics, law of carriage, network analysis, transport geography, intermodal transport, transport \&environment, Highway engineering \&infrastructure Road Traffic Principles and supply chain management.

2) Rail Transport: History of Transport, Locomotive and characteristics, rollin stocks and ballasting, Yard maintenance control, signaling and rail traffic management, Information and rail traffic passenger management

3) Maritime Transport: Shipping logistics, freight forwarding practice, port administration, navigation, maritime law, voyage costing, marine insurance, shipyard technology, ship maintenance, cargo works and oceanography.

4) Aviation: Air law, ticketing\& reservation, airline management, airport operations, salesmanship, tariff, Airline regulation, Air transport economics, Passenger handling, Air transport finance and Air transport scheduling.

5) Tourism: Relationship between transport and tourism, managing tourist and transport infrastructure, Human \&environmental impacts of tourist,managing supply and demand of tourism, future of tourism and challenges.

6) Planning: land use, Current transport legislations, transport policy, modeling, construction management, Poission distribution, Queue theory, Trip generation, Distribution, Modal split and Traffic assignment, simulation, Modal characteristics, location and Graph theory.

Analysis of the performance of the selected schools based on six criteria

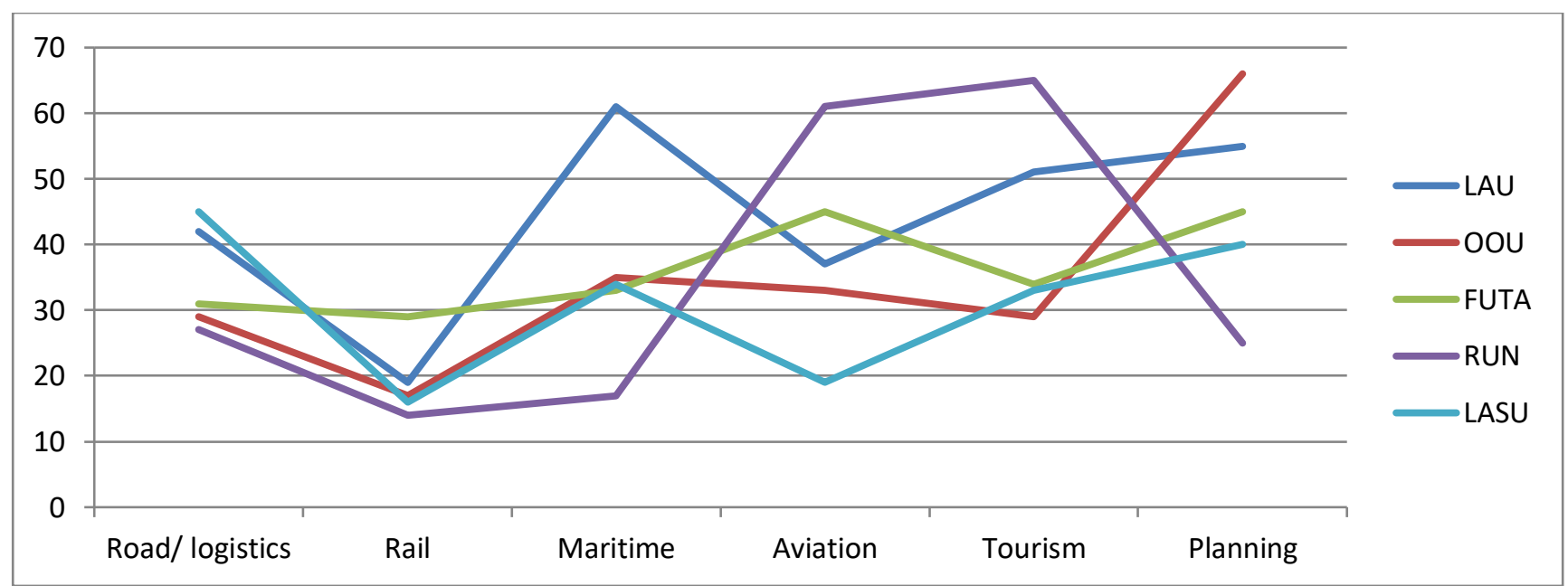

Fig 4.1: Aggregate scores of selected universities on six major courses Source: Authors' Analysis (2017)

From the figure 4.1 above, all the schools sampled do not actively participate in Rail transport while they need to improve on their collective interest in Road and Logistics that LASU has the highest strength. RUN has strength in Aviation and Tourism, lowest. LAUTECH has strength in Maritime, average on Aviation. Products of OOU scored the highest mark in Transport Planning. FUTA does not lag behind in any of the selected courses.

The following factors were identified to be the factors that can enhance qualitative transport and logistics education in Nigeria:

1. Lecturers' practical skills 
2. Lecturers international exposure and 11. Students willingness to study experience

3. Lecturers' academic qualification

12. Functional library

13. Functional electricity

4. Lecturers' aptitude to lectures

5. Lack of prejudice of lecturers

14.Performance assessment and monitoring system

6. Lecturers' ability in research

7. Availability of instructional aids

15. University result management \& computation policies

8. Availability of practical materials and Among these 15 identified factors, only five infrastructure

9. Lecturers' eagerness to information

10. Organizational structure were extracted using Principal Component Analysis to 8 eight factors. See Table 4.1 below:

Table 4.1 Total Variance Explained

\begin{tabular}{|c|c|c|c|c|c|c|c|c|c|}
\hline \multirow[b]{2}{*}{ Component } & \multicolumn{3}{|c|}{ Initial Eigenvalues } & \multicolumn{3}{|c|}{ Extraction Sums of Squared Loadings } & \multicolumn{3}{|c|}{\begin{tabular}{|l|l|}
$\begin{array}{l}\text { Rotation Sums of Squared } \\
\text { Loadings }\end{array}$ & \\
\end{tabular}} \\
\hline & Total & $\begin{array}{l}\% \\
\text { Variance }\end{array}$ & of Cumulative \% & Total & $\%$ of Variance & Cumulative \% & Total & $\begin{array}{l}\% \\
\text { Variance }\end{array}$ & $\begin{array}{l}\text { Cumulat } \\
\text { ive } \%\end{array}$ \\
\hline 1 & 3.231 & 40.387 & 40.387 & 3.231 & 40.387 & 40.387 & 2.384 & 29.800 & 29.800 \\
\hline 2 & 1.613 & 20.163 & 60.550 & 1.613 & 20.163 & 60.550 & 1.335 & 16.685 & 46.485 \\
\hline 3 & 1.021 & 12.760 & 73.310 & 1.021 & 12.760 & 73.310 & 1.244 & 15.544 & 62.029 \\
\hline 4 & .809 & 10.113 & 83.423 & 809 & 10.113 & 83.423 & 1.238 & 15.475 & 77.504 \\
\hline 5 & .616 & 7.698 & 91.121 & 616 & 7.698 & 91.121 & 1.089 & 13.616 & 91.121 \\
\hline 6 & .365 & 4.561 & 95.682 & & & & & & \\
\hline 7 & .226 & 2.831 & 98.512 & & & & & & \\
\hline 8 & .119 & 1.488 & 100.000 & & & & & & \\
\hline
\end{tabular}

Extraction Method: Principal Component Analysis.

Source: Authors' computation (2017)

The assessment was conducted on eight factors using the collected information from the respondents with orthogonal rotation (varimax). Although the sample size was poor as the Kaiser-Meyer-Olkin Measure of Sampling
Adequacy was 0.59 but was significant as indicated in the table 4.2. However, it was the best measure to assess the components to evaluate Transport and Logistics education among selected schools in Nigeria.

\section{Table 4.2: KMO and Bartlett's Test}

KMO and Bartlett's Test

\begin{tabular}{|ll|l|}
\hline Kaiser-Meyer-Olkin Measure of Sampling Adequacy. & Approx. Chi-Square & .598 \\
Bartlett's Test of Sphericity & Df & 162.294 \\
& Sig. & 28 \\
\hline
\end{tabular}

Source: Author's computation, 2017

The \% of variance of extracted factors were The rotated factor loadings actually explained summarized in the table 4.2 the strongness of these factors as indicated in the table 4.2 
Table 4.3: Rotated matrix Rotated Component Matrix ${ }^{\mathrm{a}}$

\begin{tabular}{|c|c|c|c|c|c|}
\hline & Comp & & & & \\
\hline & 1 & 2 & 3 & 4 & 5 \\
\hline $\begin{array}{l}\text { Lecturers PS } \\
\text { Infrastructure } \\
\text { Qualification } \\
\text { Experience } \\
\text { Policy } \\
\text { S/willingness } \\
\text { Assessment } \\
\text { Eagerness }\end{array}$ & \begin{tabular}{|l}
.891 \\
.887 \\
.811
\end{tabular} & $\begin{array}{l}.921 \\
.576\end{array}$ & $\begin{array}{l}.434 \\
.943\end{array}$ & $\begin{array}{l}.532 \\
.926\end{array}$ & 987 \\
\hline
\end{tabular}

Extraction Method: Principal Component Analysis.

Rotation Method: Varimax with Kaiser Normalization.

a. Rotation converged in 6 iterations

Examining this rotated component matrix in Table 4.3, Component 1 focused on Lecturers Practical skills, Infrastructure and Qualification. This connotes that, the practical skill of university teachers is very crucial to the performance and outcome of the graduates of such institution. Similarly, there must be adequate infrastructure in place for the lecturers and student to work with which will enable them to function as required. The more educated a lecturer, the more he will be able to impact knowledge under normal and reasonable circumstance. The respective values of $0.891,0887$ and 0.811 indicated that this are the major factors in evaluation of Transport and Logistics education in Nigeria.

Under the second component, the experience of the lecturer and the policy of the school are also the principal factors in evaluating the educational system with 0921 and 0.576 values respectively. The policy cuts across because it is responsible for students' willingness and Assessment as can be witnessed in column 3 and 4 table 5 . On the last note, the eagerness to information is crucial in learning environment, as such is a powerful tool in evaluation of educational performance.

\section{CONCLUSION AND RECOMMENDATIONS}

The programme of Transport and Logistics in some Southwestern Nigerian universities are similar except for those tailored towards specific areas. Hence, the products of these universities are groomed to contribute their expertise academic knowledge to the transport industry. It has been revealed that, Rail transport management should be addressed by all the universities involved in transport studies. Again, there is need to improve on all areas of courses/modes selected for this assessment as they have not performed beyond $70 \%$. Moreover, transport studies go beyond classroom theoretical lectures. Students should be exposed to practical in order to be fully equipped for the challenges in the industry. Again, there should be no student of transport school that should not be able to know the mechanics of vehicle operations even though they are to manage transport operations and systems. Transport programmes should have teaching aids and simulator for road and air transports. All segments at which professional study is sought like different packages for practitioners on road safety Federal Road Safety Corps and Vehicle Inspection Officials (FRSC, VIO), shipping, aviation, logistics, forwarders, logistics managers and administrators should be created. It true that some universities recognize this but, they have not been able to blend the art and science together.

The yardstick to enforce and monitor the course curriculum and to evaluate students' performance and compliance of lecturers' teaching what the student should know in the field of transport and logistics education in Nigeria is weak. Unlike what is obtainable in the private sector, where workers are put on their toes to meet up with daily output which will be known in no distant time if he/she fails as a result of daily assessment. There ought to be a 
quality assessment standard in form of mock examination conducted by NUC with a view to compare the grades with that of universities per session in order to enhance academic standards. The National Universities Commission has a big role to play and the commission should not just monitor per session or occasionally but visit the universities or fathom out modalities, possibly automated information monitoring system that can better enhance qualitative education in Nigeria. There should be modality for ensuring adequate and accurate lectures are delivered and received by students; the students' performance in the area of examination and grades are well monitored and guided and the NUC provides adequate support in terms of accreditation of schools that complied with standard academic prerequisites. The Transport and Logistics programmes should be tailored to equipping students in practical skills across all the modes of transport in order to make graduates to be self sustained. Somuyiwa (2017) suggested the following recommendations to boost the relevance and both professional and academic knowledge of Transport and Logistics Education in Nigeria:

- There should be introduction of safety education at high school level

- Incorporation of Local contents into CILT Professional examinations relating to level of literacy, types of Professionals that are relevant to Transport Industry. For instance, through appropriate agencies, Ministries, Non Governmental Organisations (NGOs) / and Community Based Organisations (CBOs) , some artisans and others alike should be subtly compelled to undergo some courses that are related to Transport and Logistics such that peculiarity and Professionalism can be enhanced and Promoted

- Advanced Diploma certificate holders of CILT should be excempted from certain courses in Transport Education courses
Masters degree holders should not be excepted from taking some courses based on the fact that the principles and teachings vary and they are potential teachers of coming generations

- Professionals should handle courses in order to provide practical and field experience trainings.

- Industrial visitation should be encouraged and made compulsory among the students and should be part of the curriculum.

- There is need to re-orientate the existing practitioners in the industry as through symposium, seminars and workshops. E.g NURTW, Artisans e.t.c

The paper concluded that, Nigerian Universities Commission (NUC) and the selected universities as the representatives of other universities must fathom more and better modalities that can enhance lecture delivery, curriculum structure, students' grades assessment, monitoring, training and re-training of university staffs not only on theoretical base, but skill acquisition also in relation to specific disciplines across Nigerian Universities in order to realize the expected performance in our schools.

\section{References}

1. Abdalla Uba Adamu (2012):Motionless Points in Chaos: Education Reforms, Innovations and the Challenges for Higher Education in Nigeria: Bayero University Kano

2. Akinmusuru JO (2009) The curriculum as a living document for achieving education for sustainable development. In: Proceeding of the 12th general conference on sustainable Development in Africa: The Role of Higher Education, Abuja Nigeria 4-9 May.

3. Bamiro (2012) The Nigerian university system and the challenges of relevance In: Convocation Lecture University of Lagos, Akoka-Lagos 12 January

4. Bawa-Allah (2008): Lagos State University, School of Transport Management Students Handbook

5. Coombs PH (1970): World educational crisis: A system approach. New York: Oxford university press. 
6. Ehiametalor ET (1988) Perspectives on National development: A book of readings. Benin: University of Benin press

7. Ezenyilimba E (2015): The Challenges of Tertiary Management Education and Strategic Learning Panacea in Nigeria Department of Marketing, Nnamdi Azikiwe University, Awka, Nigeria. International Journal of Academic Research in Business and Social Sciences June 2015, Vol. 5, No. 6 ISSN: 2222-6990

8. Federal Ministry of Education (2004): National Policy on Education. Lagos: Education research and development council.

9. Ighodo PO (2011): Higher Education in Nigeria and the Challenges ahead European Journal of Educational Studies 3(2), 2011 (c) 20011 Ozean Publication

10. Kamm RB, (1983): Significant elements of a University. Oklahoma State alumnus, 4 January 8.

11. National Universities Commission (2001): "Nigerian Universities Inaugural Lectures series", Published by National Universities Commission, Abuja.

12. Ogunsanya, A.A (2004): " Directions of Transport research and development in Nigeria in the 21st century". A paper presented at the National conference and Alumni Re-union, Centre for Transport Studies, Ago- Iwoye.

13. Olson C.O and Wyett,J.L (2000): A Conceptual K-6 Teacher Competency Model for Teaching Engineering

14. Onah, J.O. (1979) "Marketing in Nigeria", 1st Edition Cassel Company Ltd London.

15. Oyesiku O.O (2016): Transport and Logistics Professionalism and Education Regulations: A Prerequisite to Transport and Economic Development in Africa

16. Romina I.A (2013): Challenges of Quality in Higher Education in Nigeria in the 21st Century International Journal of Educational Planning \& Administration. ISSN 2249-3093 Volume 3, Number 2 (2013), pp. 159-172 @ Research India Publications

17. Somuyiwa A.O, Oyesiku, O.O and Dosunmu V.A (2011): Transport and logistics research and its impact on capacity building of local institutions in Nigeria American Journal of Scientific and Industrial Research @ 2011, Science Huß, ISSN: 2153-649X doi:10.5251/ajsir.2011.2.4.559.566

18. Somuyiwa, A. O. (2009): "Understanding Transport and Logistics". Being a Paper presented at Workshop on Young Members
Forum of Chartered institute of Logistics and Transport, Nigeria.

19. Somuyiwa A.O (2017):Transport and Logistics Education: Impetus For Human Capital Development being a lecture delivered at The presentabtion of CILT bill at House of Representative in Abuja, Nigeria

20. Ukeje BO (1996) In: Lassa PN (ed) Teacher education-An imperative for national development. Kaduna: NCCE.

21. World Bank (1999): World development report, knowledge for development. Washington D. C:

22. World Bank (2004) Improving Tertiary education in Sub-Sahara Africa: Things that work. Report of a regional training conference, Accra, Ghana.

23. Yassing M.S (2000): The training of marine engineers : present methods and future directions in developing countries (Africa). World Maritime University Dissertations. Paper 397.

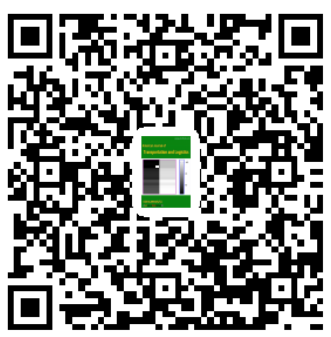

